\title{
Lichen diversity as indicators for monitoring ecosystem health in Rawa Danau Nature Reserve, Banten, Indonesia
}

\author{
RIDA OKTORIDA KHASTINI", INDAH JUWITA SARI, YOLA HERYSCA, SITI SULASANAH \\ Department of Biology Education, Faculty of Teacher Training and Education, Universitas Sultan Ageng Tirtayasa. J1 Raya Jakarta Km 4, Pakupatan, \\ Serang 42124, Banten, Indonesia. Tel.: +62-254-2803330 ext. 111, Fax.: +62-254-281254, “email: rida.khastini@untirta.ac.id.
}

Manuscript received: 6 October 2018. Revision accepted: 27 January 2019.

\begin{abstract}
Khastini RO, Sari IJ, Herysca Y, Sulasanah S. 2018. Lichen diversity as indicators for monitoring ecosystem health in Rawa Danau Nature Reserve, Banten, Indonesia. Biodiversitas 19: 489-496. Study on environmental changes is very important in present circumstances throughout the world. Lichen biodiversity may provide an excellent measure in bio-monitoring on the ecosystem health of nature reserve areas such as Rawa Danau in Banten Province, Indonesia. At present, this area is highly disturbed due to ecological factors and human activities such as land use for agricultural land and residential area. The objective of this research is to provide the information needed for assessing ecosystem health which will be revealed by the diversity of lichens in the study area. The study was conducted using transect-based plot in three landscapes: residential area, primary forest and secondary forest, while exploration technique was carried out in freshwater swamp area. The cover for lichen species in the substrates and the number of species present were recorded. Shannon-Wiener diversity index was also calculated. A total of 86 specimens were collected from these four areas which resulted in the occurrence of 25 species of lichens belonging to 20 genera and 14 families. Shannon-Winner's diversity index are ranging from 1.7197 at residential area to 2.6678 at swamp area. The variation in species composition is likely associated with the abiotic and biotic factors of each landscape with the differences in lichen diversity across landscapes suggest an altered environmental condition of in Rawa Danau. The results of this study can be used as baseline information of ecosystem health of Rawa Danau Nature Reserve in the face of future environmental changes.
\end{abstract}

Keywords: Ecosystem health, lichen diversity, rawa danau, bio-monitoring, habitat

\section{INTRODUCTION}

Monitoring and evaluation of environmental changes are aimed to develop awareness on ecosystem health and to assess environmental dynamics particularly those caused by human activities. These activities can be performed using three types of parameter, which are physical, chemical and biological parameter (Kuldeep and Prodyut 2015). Using physicochemical methods (Matusmoto and Mizoguchi 1995) will provide accurate and reliable data, yet the expensive instruments combined with high-intensity application are rarely feasible to carry out across large areas at adequately representative sampling sites. Moreover, physicochemical methods in spite of their accuracy, fail to provide information on possible effects of various pollutants on living organisms (Awang 1995). Therefore biological parameters are used as alternative way to measure environmental quality. In this context, lichens are potential to be used as bioindicator for ecosystem health. Lichens are sensitive to a wide range of changes in biotic and abiotic variables in ecosystem. This sensitivity is due to particular physiological characteristics of lichen which allows them to be used as indicators for monitoring of habitat changes as well as providing an integrated measure of all disturbances occurring in their environment. In terrestrial ecosystems, epiphytic lichens are probably the most widely used as bio-monitors (Nimis et al. 2002) which can detect and monitor various pollutants.

Lichen is a symbiotic organism, made up of two or more different organisms living together between the fungi as mycobiont of the Ascomycetes group and the Basidiomycetes, with algae, the photobiont from the Cyanobacteria or Chlorophyceae group. The development of a lichen thallus is often so integrated that they had been perceived and studied as single organism until quite recently, and have often been referred to as the ultimate example of mutualism. The fungus provides the body in the form of thallus in which the algal partner can live and is being protected from damaging conditions such as high levels of light and water and mineral supplies. Based on the type of growth, lichen is divided into seven groups of foliose, fruticose, crustose, squamulose, leprose, filamentous and placodioid (Dobson 1992), but the commonly found are foliose, fruticose, and crustose (Rout et al. 2010). Up to date, the available knowledge concerning the lichen diversity of Indonesia especially in Banten Province and its relation with the ecosystem health is very limited.

Assessment on lichen diversity is commonly used in the context of monitoring of environmental changes. For example, air pollution uses standardized and widely adopted methodology as the guideline proposed by Asta et al. (2002). This index, which takes into account both species richness and abundance, demonstrates high correlation with atmospheric pollution (Amman et al. 1987) and environmental quality (Castello and Skert 2005). Research conducted by van Dobben and ter Braak (1999) measuring the concentration of $\mathrm{SO}_{2}, \mathrm{NO}_{2}$ and $\mathrm{NH}_{3}$ in the 
atmosphere as a source of pollutants shows relationship with the presence and abundance of lichen with lichen is very sensitive to $\mathrm{SO}_{2}$. Other research on lichen diversity to assess the quality of environment was carried out by de Silva and Sinanayake (2015) in pine plantation and adjacent secondary forests in Sri Lanka. The results that these two habitats have low environmental quality due to human activities which is indicated by the low density of lichen in both habitats.

The Rawa Danau is a nature reserve area located in Serang, Banten Province, Indonesia with high biodiversity importance. Rawa Danau was enacted as nature reserve through the Ministry of Forestry decision No.SK.3586/Menhut-VII/KUH/2014 with total extent of area about 3.542,70 Ha. Ecologically, Rawa Danau is the last and the only mountainous freshwater swamp that still exists in Java Island (Melisch et al. 1993). The establishment of Rawa Danau as nature reserve also creates a buffer zone on surrounding vegetation to enhance the protection of biodiversity. Therefore, the sustainability of surrounding ecosystems is very important. At present, this area is highly disturbed due to human activities. The swamp has been drained to be converted into agricultural lands. There have been studies related to environmental bioindicators in Rawa Danau. Yulianto et al. (2005) observed holocene pollen and charcoal records from the lowland areas of tropical swamps in Rawa Danau. Their results show that there are changes in vegetation in several hundred years caused by climatic and environmental changes as well as disturbances by human activities. However, research related to lichen has not been done much despite the fact that lichen is a group of organisms that are very sensitive to environmental changes. The objective of this research is to provide baseline information for ecosystem quality assessment in Rawa Danau Nature Reserve in regard to lichen diversity in the study area.

\section{MATERIALS AND METHODS}

\section{Study area}

The research is conducted in Rawa Danau Nature reserve in Banten Province, Indonesia (Figure 1). Geographically, the area is located at $6^{\circ} 8^{\prime}-6^{\circ} 11^{\prime}$ South Latitude and $105^{\circ} 56^{\prime}-106^{\circ} 04^{\prime}$ East Longitude at an altitude of $300-600 \mathrm{~m}$ above mean sea level with total area of 3.542,70 Ha. The swamp area has a water outlet through Cidanau River. The main vegetation types in Rawa Danau area are mixed swamp forest, swamp forest, open herbaceous swamp and dryland, hill forest (Endert 1932; Melisch et al. 1993). According to Schmidt and Ferguson (1951) climate in the study area is classified as type A with annual rainfall about $2151 \mathrm{~mm} /$ year. Dry season occurs between June and August and rainy season is from September to May. The annual precipitation of the study area is about $2500 \mathrm{~mm}$ and daily temperatures is ranging from 17 to $25^{\circ} \mathrm{C}$.

\section{Sampling methods}

The field works were carried out during February-May 2018. Lichen specimens were collected from plots in four sites representing different landscape using transect method (Table 1) following the manual of sampling technique for non-vascular plants (Eldrige et al. 2003). Three sites were residential area, primary forest and secondary forest and were divided into three plots $(5 \times 5 \mathrm{~m})$ systematically established along 100-meter belt transects and numbered 13. The other site was freshwater swamp area in which lichens were sampled using exploration roaming method along the water body. Lichens growing on different substratum were sampled and collected. Foliose lichens were collected with part of the substrate to prevent any damages to the thallus and rhizines. Crustose species were uprooted by taking sufficient bark from the trees using iron scalpels.

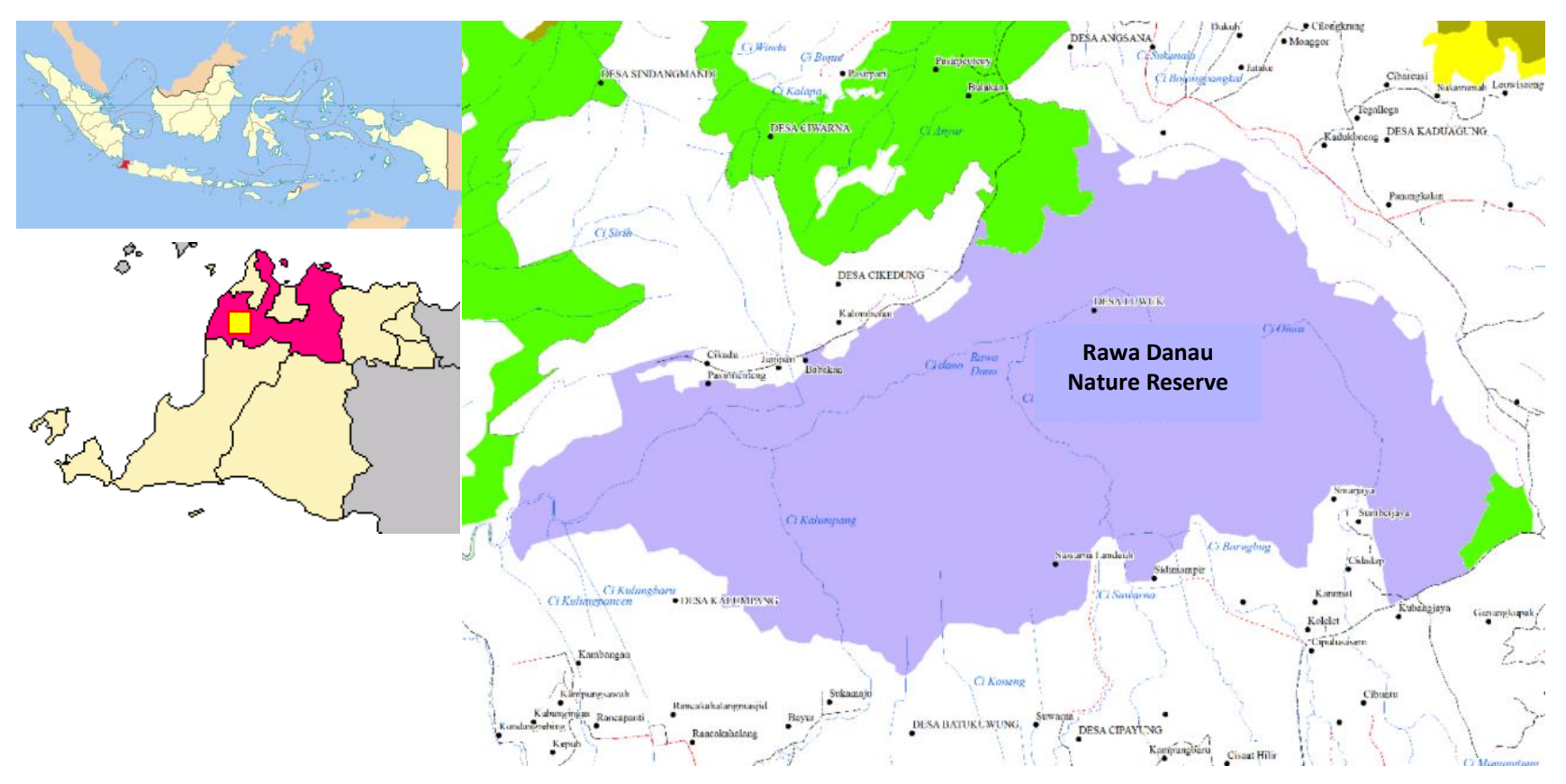


Figure 1. Map of study area of Rawa Danau Nature Reserve, Banten, Indonesia (BBKSDA 2016)

Table 1. Site selected for lichen study in Rawa Danau Nature Reserve, Banten, Indonesia

\begin{tabular}{|c|c|c|c|c|c|}
\hline Site & Location & $\begin{array}{l}\text { Temp. } \\
\left({ }^{\circ} \mathrm{C}\right)\end{array}$ & $\begin{array}{l}\text { Humidity } \\
\quad(\%)\end{array}$ & $\begin{array}{c}\text { Light } \\
\text { intensity } \\
(\text { Lux })\end{array}$ & Characteristic of vegetation \\
\hline RA & $\begin{array}{l}6^{\circ} 9^{\prime} 32,5^{\prime \prime} \mathrm{S} \\
105^{\circ} 57^{\prime} 47,8^{\prime} \mathrm{E}\end{array}$ & 30.8 & 88 & 2817 & $\begin{array}{l}\text { Dominated by planted vegetation such as Melinjo (Gnetum gnemon), } \\
\text { Kakao (Theobroma cacao), Kihujan (Samanea saman), Mango } \\
\text { (Mangifera indica) dan Durian (Durio zibethinus) }\end{array}$ \\
\hline $\mathrm{PF}$ & $\begin{array}{l}6^{\circ} 9^{\prime} 31,2^{\prime} \mathrm{S} \\
105^{\circ} 58^{\prime} 38,77^{\prime} \mathrm{E}\end{array}$ & 28.4 & 91 & 1737 & $\begin{array}{l}\text { Tropical trees dominated by Buni (Antidesma bunius) and Kitoke } \\
\text { (Albizia lebbeck) }\end{array}$ \\
\hline SF & $\begin{array}{l}6^{\circ} 9^{\prime} 24,8^{\prime \prime} \mathrm{S} \\
105^{\circ} 58^{\prime} 35,6^{\prime \prime} \mathrm{E}\end{array}$ & 30.6 & 78.7 & 1603 & $\begin{array}{l}\text { Tropical trees dominated by Bubuay (Plectocomia elongata), } \\
\text { Kitoke (Albizia lebbeck), Langkap (Arenga obtusifolia), } \\
\text { Pinangsih (Villebrunea rubescens), Mara (Macaranga tanarius), } \\
\text { Teureup (Artocarpus elasticus), and Huru (Elaeococarpus sp.) }\end{array}$ \\
\hline S & $\begin{array}{l}6^{\circ} 9^{\prime} 58,6^{\prime} \mathrm{S} \\
105^{\circ} 57^{\prime} 34,6^{\prime} \mathrm{E}\end{array}$ & 29.5 & 91.6 & 434 & $\begin{array}{l}\text { Swamp vegetation dominated by Gempol (Nandea cordatus) and } \\
\text { Jajawai (Ficus microcarpa) }\end{array}$ \\
\hline
\end{tabular}

Immediately after collection, samples were cleaned to remove bark residues and other extra materials for their identification. Ordinary zip-lock plastic bags were used as temporary storage to collect lichen specimens. At each sampling location, the GPS location, relative humidity, temperature, light intensity, and vegetation characteristics were recorded.

\section{Lichen Identification}

Morphological characters of thalli fruiting bodies were examined using magnifying lenses (x10) and under dissection microscopic observations (Leica microscope dm500). Components of lichen may react with certain chemical test by giving color reactions which assists in the identification of a species. Chemical spot tests were carried out in this research using freshly prepared Sodium hypochlorite solution $\left(\mathrm{Ca}(\mathrm{OCl})_{2} \quad 10 \%\right.$ aqueous solution of Potassium hydroxide and iodine. Description was made based on the data obtained from the results of morphological and chemical characterization to assist identification of species name. Identification of species name was carried out according to lichen identification keys and pictorial guides (Sipman 2003).

\section{Lichen diversity index}

Lichen diversity of each site was determined using Shannon's diversity index (Batten 1976).

$$
\begin{aligned}
& H^{\prime}=-\sum p i(\log p i) \\
& \text { Where, } \\
& H^{\prime}=\text { Diversity } \\
& p i=\text { the proportional abundance of the } i \text { th species }
\end{aligned}
$$

The areas were categorized into four classes according to the calculated values of lichen diversity indices: sites with the diversity index between 0.80 and 0.89 were categorized as low; between 0.90 and 0.99 as moderate; between 1.00 and 1.09 as high and values greater or higher than 1.10 as very high. These ranges can be used as indicator of environmental quality and future biomonitoring studies.

\section{RESULTS AND DISCUSSION}

\section{Results}

Data obtained from the fieldworks and laboratory analysis are compiled in Table 2 in which the lichen species are arranged in alphabetical order according to lichen family. The morphological characters of a lichen specimen were observed. The upper surface of lichen which has to be noted was the color of the thallus, texture (smooth, rough, warty), presence of isidia, soredia or pycnidia, the branching pattern, length of marginal lobes, and presence of hair-like structures. While the lower surface indicator was the color of lower surface, presence of any pores, presence or absence of rhizines.

A total of 86 specimens were collected from the four areas which resulted in the occurrence of 25 species of lichens belonging to 20 genera and 14 families. The reported lichen families were Arthoniaceae (five species), Parmeliaceae (four species) Caliciaceae, Physciaceae, Porinaveae, Ramalinaceae (two species each), Chrysothricaceae, Graphidaceae, Monoblastiaceae, Pertusariaceae, Roccellaceae, Stereocaulaceae, Teloschistaceae, Verrucariaceae (one species each).

Taxonomic description of recorded species is provided here.

Family Physciaceae.

Two species of Hafellia belong to Family Physciaceae were found in the study area. Both species are corticolous. Hafellia sp. and Hafellia levieri are closely related and have the same characteristics. Both species have crustose thallus, grayish-white $1-5 \mathrm{~cm}$ wide, thin, thick and inrolled when young, moderately thick at maturity and 8-spored asci. In the study area, Hafellia sp. was growing on the stone surface and the chemical spot test show the thallus are $\mathrm{I}-, \mathrm{K}+, \mathrm{C}+, \mathrm{KC}+$. Hafellia levieri occurred on bark and wood of Gnetum gnemon, Samanea saman, Durio zibethinus and Ficus microcarpa tree with thallus are I+, $\mathrm{K}+, \mathrm{C}+, \mathrm{KC}+$. According to Puswald et al. (1994), Hafellia 
is distributed in wet forest such as cool temperate rainforest.

Table 2. Species Composition of Lichen Species in Rawa Danau Nature Reserve, Banten, Indonesia

\begin{tabular}{|c|c|c|c|c|c|c|c|c|c|c|}
\hline \multirow{2}{*}{ Family } & \multirow{2}{*}{ Species } & \multirow{2}{*}{ Morphology } & \multicolumn{4}{|c|}{ Chemical spot tests } & \multicolumn{4}{|c|}{ Frequency $(\%)$} \\
\hline & & & I & $\mathbf{K}$ & $\mathbf{C}$ & KC & RA & PF & SF & $\mathbf{S}$ \\
\hline \multirow[t]{2}{*}{ Physciaceae } & Hafellia levieri & Crustose & + & + & + & + & 39.84 & - & 9.7 & 6.18 \\
\hline & Hafellia sp. & Crustose & - & + & + & + & - & 4.62 & - & - \\
\hline \multirow[t]{5}{*}{ Arthoniaceae } & Cryptothecia sp. & Crustose & - & + & + & + & 23.75 & 25 & 2.85 & - \\
\hline & Cryptothecia effusa & Crustose & - & + & + & + & - & 18.82 & - & - \\
\hline & Cryptothecia faveomaculata & Crustose & - & + & + & + & - & 11.41 & - & - \\
\hline & Cryptothecia striata & Crustose & - & + & + & + & 14.94 & - & 13.7 & - \\
\hline & Arthonia sp. & Crustose & - & + & + & + & - & 4.62 & - & 4.12 \\
\hline Teloschistaceae & Caloplaca sp. & Crustose & + & + & + & + & 2.68 & - & 14.85 & 4.12 \\
\hline Stereocaulaceae & Lepraria sp. & Crustose & + & + & + & + & 6.89 & - & 7.99 & 5.15 \\
\hline Graphidaceae & Graphis sp. & Crustose & + & + & + & + & 6.51 & 2.46 & 8.56 & 2.06 \\
\hline \multirow[t]{2}{*}{ Ramalinaceae } & Bacidia sp. & Crustose & - & + & - & + & 1.53 & - & - & - \\
\hline & Phyllopsora sp. & Crustose & - & + & + & + & - & - & - & 7.21 \\
\hline Pertusariaceae & Pertusaria sp. & Crustose & - & + & + & + & - & 24.38 & - & - \\
\hline \multirow[t]{2}{*}{ Porinaceae } & Porina sp. & Crustose & - & + & + & + & - & 1.54 & - & - \\
\hline & Porina distans & Crustose & - & + & + & + & - & - & - & 1.03 \\
\hline Verrucariaceae & Hydropunctaria maura & Crustose & - & + & + & + & - & - & 2.28 & 2.06 \\
\hline Roccellaceae & Dichospiridium sp. & Crustose & - & + & + & + & - & 0.3 & - & - \\
\hline Monoblastiaceae & Musaespora sp. & Crustose & + & + & + & + & - & - & 38.2 & - \\
\hline Chrysothricaceae & Chrysothrix xanthina & Crustose & - & + & + & + & - & - & - & 14.43 \\
\hline \multirow[t]{2}{*}{ Caliciaceae } & Buellia sp. & Crustose & + & + & + & + & - & - & 1.71 & 5.15 \\
\hline & Dirinaria $\mathrm{sp}$ & Foliose & - & + & + & + & - & - & - & 10.3 \\
\hline \multirow[t]{4}{*}{ Parmeliaceae } & Parmotrema sp. & Foliose & - & + & + & + & 3.83 & - & - & - \\
\hline & Flavoparmelia caperata & Foliose & - & + & + & + & - & - & - & 14.43 \\
\hline & Myelochroa obsessa & Foliose & - & + & + & + & - & - & - & 11.3 \\
\hline & Anzia sp. & Foliose & - & + & + & + & - & - & - & 12.37 \\
\hline
\end{tabular}

Note: I: Iodium, K: KOH 10\%, C: $\mathrm{Ca}\left(\mathrm{OCl}_{2}, \mathrm{KC}: \mathrm{KOH} 10 \%+\mathrm{Ca}(\mathrm{OCl})_{2}\right.$, RA: Residential Area, PF: Primary Forest, SF: Secondary Forest, S: Swamp

Family Arthoniaceae

The genus of Cryptothecia was firstly described by Stirton (1877) and is belong to the Family Arthoniaceae. In the study area, 4 species of Cryptothecia were found. The observations indicate that the characters across family member rather vary and may range from thin and continuous to thick and superficial. Thallus are crustose, corticolous while well-defined ascomata are lacking. The chemical spot test shows that the thallus is $\mathrm{I}-, \mathrm{K}+, \mathrm{C}+$, $\mathrm{KC}+$. The species of Cryptothecia sp. is characterized by greenish to yellowish thallus with 8-spored asci. The species grow on Gnetum gnemon, Antidesma bunius, Villebrunea rubescens tree and some of them can be found grow on the stone surface. Cryptothecia effuse is easily recognized by the bright greenish, crustose thallus that grows on stone surface. Similar to $C$. effuse, $C$. faveomaculata is also found to grow on stone surface while Cryptothecia striata is characterized by the greenish grey to greyish white thallus with granular isidia-like structures grow on the bark of Gnetum gnemon, Macaranga tanarius, Artocarpus elasticus tree

Arthonia sp. also belongs to family Arthoniaceae. Different from Cryptothecia sp., it is characterized by thin crustose lichen, white, powdery and can be found on Albizia lebbeck and Nandea cordatus tree. The chemical spot test shows that the thallus is $\mathrm{I}-, \mathrm{K}+, \mathrm{C}+, \mathrm{KC}+$. According to Kantvilas and Wedin (2015), Arthonia is a cosmopolitan genus of ascomycetes fungi that can be found in wide range of habitats from steppes and savannahs to closed wet forests.

\section{Family Teloschistaceae}

Caloplaca is one of the most widely distributed and common genera of the lichen family of Teloschistaceae (Joshi and Upreti 2007). Arup et al. (2013) state that Caloplaca sp. is generally abundant and speciose only on calcareous rock, such as limestone or concrete, and in a eutrophicated condition such as on trees under wounded bark, seashores or walls used by dogs. However, different condition was noted in the study site in which Caloplaca thallus crustose is found on the bark of Theobroma cacao L., Macaranga tanarius and Ficus microcarpa tree. There was no Caloplaca sp. found grew in stone surface. The chemical spot test shows that the thallus is $\mathrm{I}+, \mathrm{K}+, \mathrm{C}+$, $\mathrm{KC}+$. Thallus crustose are yellow to brownish yellow with irregular surface. Caloplaca sp. has 8 spores per ascus.

\section{Family Stereocaulaceae}

Lepraria sp. is a member of Family Stereocaulaceae that grows on substrate patches of granular and it looks like dust grains which made of soredia. The ascomata cannot be observed. The species is widely distributed worldwide with the highest diversity is probably in cool-temperate and boreal areas (Nash et al. 2004). In the study site, the greyish thallus of Lepraria sp. was found in in the bark of Mangifera indica L, Villebrunea rubescens, Elaecocarpus 
sp. and Ficus microcarpa tree as the substrates. The chemical spot test shows that the thallus is $\mathrm{I}+, \mathrm{K}+, \mathrm{C}+$, $\mathrm{KC}+$.

\section{Family Graphidaceae}

Graphis sp. that belong to family Graphidaceae has crustose and corticolous thallus with cream and grayish green. The structure of apothecia raises from thallus. Thallus is $\mathrm{I}+, \mathrm{K}+, \mathrm{C}+, \mathrm{KC}+$. The member of family Graphidaceae is by far the most dominant element in tropical crustose lichen communities (Lücking et al. 2008). Graphis species are commonly found in montane and dry tropical forests in semi-exposed situations (Pitakpong et al. 2015). In the study site, thallus was found in in the bark of Mangifera indica L, Antidesma bunius Albizia lebbeck, Ficus microcarpa tree. Graphis sp. has 8 spores per ascus with transversely septate.

\section{Family Ramalinaceae}

Two species from family Ramalinaceae were found in the study site. Bacidia sp. grows on the bark of Gnetum gnemon tree and has corticolous thallus, indeterminate with the thallus are greenish grey, corticate, consisting of granulose microsquamules without a prothallus. Apothecia are present and have 3 septate spores. The chemical spot test shows that the thallus is $\mathrm{I}-, \mathrm{K}+, \mathrm{C}-, \mathrm{KC}+$.

Green thallus of Phyllopsora sp. was found to grow on the bark of Ficus microcarpa tree. Isidia and medium brown of Apothecia were observed in the thallus. The thallus is $\mathrm{I}-, \mathrm{K}+, \mathrm{C}+, \mathrm{KC}+$. The thallus morphology and anatomy of modern Phyllopsora species have been described in detail by Brako (1991). Phyllopsora species are predominantly found in tropical and subtropical areas with few extensions into the temperate zone (Upreti et al. 2003).

\section{Family Pertusariaceae}

Pertusaria sp. was collected as crustose type whitegreenish with smooth surface and isidia was in the bark of Antidesma bunius, Albizia lebbeck tree and stone surface. The asci have 2 hyaline ascospores. The chemical spot test shows that the thallus is $\mathrm{I}+, \mathrm{K}+, \mathrm{C}+, \mathrm{KC}+$. According to Lumbsch and Nash (2002) the genus Pertusaria DC. has a worldwide distribution with over 350 species, being particularly common in subtropical and temperate regions.

\section{Family Porinaceae}

Two species member of Porinaceae collected have pale greenish corticolous thallus, subfruticose type, and marginal rhizines. The genus of Porina comprises at least 300 species with ecology of are found on bark, rock, and leaves in cool and warm temperate and especially subtropical and tropical regions (Mc Carthy 2000). At the study site, the thallus substrates for Porina sp. and Porina distans were tree bark of Antidesma bunius and Ficus microcarpa respectively.

\section{Family Verrucariaceae}

The species of Hydropunctaria as currently known have an epilithic thallus containing more or less discrete regions of dark pigment ('punctae' or ridges) and they grow in seashore or freshwater habitats (Gueidan et al. 2009). Thallus is $\mathrm{I}-, \mathrm{K}+, \mathrm{C}+, \mathrm{KC}+$. Hydropunctaria maura was collected from Albizia lebbeck and Nandea cordatus tree.

\section{Family Roccellaceae}

One of the family members from Roccellaceae is the species of Dichospiridium sp. which is characterized by squamulose, grey with a yellowish green tinge; prothallus with a whitish inner and brown outer part peseudoangiocarp apothecia and 4-8 septate ascospore. The chemical spot test shows that the thallus is $\mathrm{I}-, \mathrm{K}+, \mathrm{C}+$, KC+. According to Thor (1990), the species is widely distributed in Asia and also occurs in Australia and on some islands in the Pacific. In the study area, Dichospiridium sp. was found on the surface of stone.

\section{Family Monoblastiaceae}

Musaespora sp. is a family member of Monoblastiaceae. The genus Musaespora was introduced by Aptroot and Sipman (1993). The lichen is easily characterized by greyish-bronze thallus with the blackishbrown and smooth surface. The blackish-brown perithecia can be observed. In the study area, Musaespora sp. was found on Albizia lebbeck, Arenga obtusifolia and Arthocarpus elasticus tree. The thallus is $\mathrm{I}+, \mathrm{K}+, \mathrm{C}+$, $\mathrm{KC}+$.

\section{Family Caliciaceae}

In the study site, 2 species that belong to family Caliciaceae were found. The species of Buellia sp. which grow as crustose thallus on Arenga obtusifolia and Ficus microcarpa tree can be characterized by thallus $\mathrm{I}+, \mathrm{K}+, \mathrm{C}+$, $\mathrm{KC}+$. The greenish-gray thallus of Dirinaria sp. was found appressed to Nandea cordatus tree bark as the substrate. Apothecia cannot be found in the thallus. The chemical spot test shows that the thallus is $\mathrm{I}-, \mathrm{K}+, \mathrm{C}+, \mathrm{KC}+$. Elix (2009) states that this species spreads in pantropical to subtropical regions and often extends into temperate zones.

\section{Family Chrysothricaceae}

Corticolous, thin thallus of Chrysothrix xanthina is incorporated and developed aggregation in small patches. According to Liu et al. (2018), the genus of Chrysothrix which belong to the family of Chrysothricaceae is very common around the world and easy to be recognized by its bright yellowish granular thallus. Apothecia cannot be seen on the thallus. The thallus is $\mathrm{I}+, \mathrm{K}+, \mathrm{C}+, \mathrm{KC}+$. Chrysothrix usually grows on rock, tree, and wood, and has a wide distribution around the world, like Europe, North America, Australia, South America, and India (Knudsen and Bungartz 2013). In the study site, Chrysothrix xanthine grow on Ficus macrocarpa tree as the substrate

\section{Family Parmeliaceae}

Four species member of Parmeliaceae were collected from the study site. Parmotrema sp. is foliose with greygreen, smooth and shine thallus are loosely attached to the substratum on Mangifera indica tree bark. Parmotrema is one of the largest genera of parmelioid core in the 
Parmeliaceae family (Blanco et al. 2005). Soralia and rhizine can be observed in the margin. Apothecia and pycnidia is not seen on the specimens examined.

Morphologically, Flavoparmelia caperata is a corticolous, squamules lichen type with horizontal primary thallus and simple greenish white stalk like outgrowth of the thallus, subulate at base, upward micro-squamules and with granulose soredia (powdery propagules). In the study site, its thallus color is greenish brown and grow in the Ficus macrocarpa. The pale brownish Myelochroa obsessa and Anzia sp. are also found on Ficus macrocarpa tree. The asci with numerous crescent-shaped ascospores was observed under microscope. All four species member has chemistry thallus of $\mathrm{I}-, \mathrm{K}+, \mathrm{C}+, \mathrm{KC}+$.

In order to compare the lichen diversity between the different sites, the Shannon-Wiener diversity index was calculated (Figure 2). Shannon index is ranging from 1.7197 to 2.6678. The number of lichen species and diversity differs between the residential area, primary forest, secondary forest, and swamp area even though they are all under the same category of very high lichen diversity. Freshwater swamp sites have the highest diversity index while residential area has the lowest value. These results suggest that the high density of large trees in the swamp area plays important role for species richness and occurrence of some lichens. Graphis sp is widely distributed across 4 sites followed by Hafellia levieri, Hafellia sp., Caloplaca sp., and Lepraria sp. which is only present in three sites.

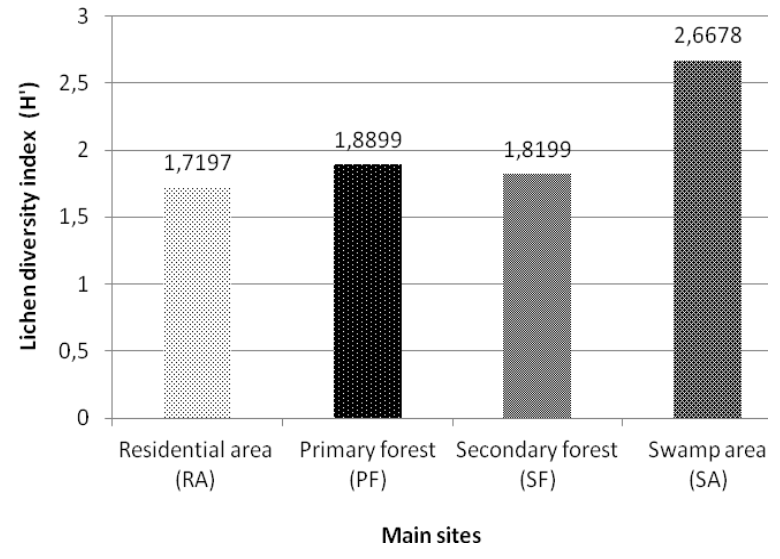

Figure 2. Lichen Diversity Index in Rawa Danau Nature Reserve, Banten, Indonesia

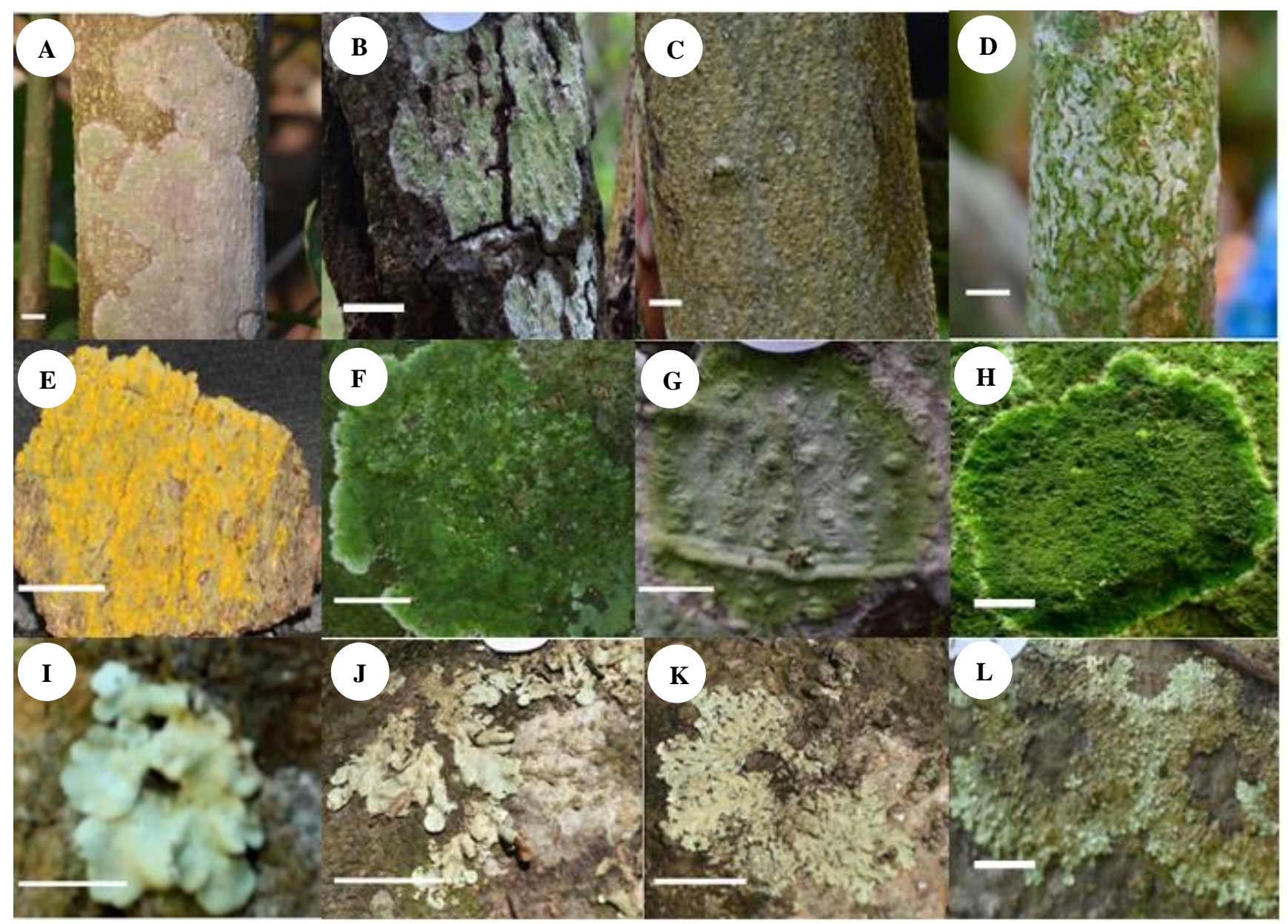


Figure 3. Morphology of lichen in Rawa Danau Nature Reserve, Banten, Indonesia. A-D. Crustose lichen on bark substrate, E-H. Crustose lichen grows on rock substrate, I-L. Foliose lichen on tree. Bar $=1 \mathrm{~cm}$

Other ecological factors such as temperature, humidity, light intensity, and vegetation types also play a vital role for colonization of lichens. Vegetation type becomes important factor which influences lichen diversity in tropical regions compared with temperate. Table 1 lists the species found in each study site. In tropical regions, the dominant lichens are corticolous, while in temperate regions, saxicolous species form the majority. Overall, the lichens in the study area exhibit great level of diversity and abundance, and seems to prefer bark of trees as their substratum. Based on observation, lichens in the form of crustose were more common which account for $80 \%$ of samples whereas foliose lichens represented $20 \%$ of samples. Lichen morphology at the study site can be seen in Figure 3.

\section{Discussion}

The conservation of nature reserve is an essential component for the maintenance of the biodiversityits contained. In Rawa Danau Nature Reserve, the area is highly affected by various factors due to ecological variables and human activities such as land use. The diversity of lichens is commonly used as a sensitive indicator of biological effects of environmental changes. Lichens have physiological responses as stress indicators which may help in detecting early signs of altered environmental conditions (Paoli and Loppi 2008) and evaluating the management of natural resources in the Nature Reserve (McMullin et al. 2013).

Research for monitoring environment by collecting lichens from the field must be continued by determining species richness and abundance and their distribution. According to Brunialti and Giordani (2003), ecological factors play an important role in the growth, development and distribution of lichen species. When natural environment is altered or transformed into different habitat with changes in vegetation types, the existence of favorable host-trees can decline, triggering changes in lichen composition and decreases in species diversity. This transformation can produce changes in microclimate conditions particularly temperature, light intensity and humidity (Hilmo and Såstad 2001).

In Rawa Danau Nature Reserves, the distribution of lichen species across four different landscapes is not uniform, reflecting variability in environmental condition between sites. Among 14 families of lichen observed in the area, Arthoniaceae become the most dominant family. This is in agreement with Sipman (2009) that the most common Ordo of lichen in tropical area such as Singapore is Arthoniales. The freshwater swamp is found to be the site with the greatest diversity of lichen since the site may create favourable local climatic condition for the growth of fungi. The microclimatic condition and vegetation type on primary forest and swamp area in this study show more favourable climatic conditions compared to the residential area as indicated by the temperature and relative humidity values (Table 1). This finding strengthens the by research Attanayaka and Wijeyaratne (2013) which found that micro-climatic factors can affect the distribution of mosses such as land use patterns, substrate $\mathrm{pH}$, and light exposure.

Green areas influence atmospheric variables such as air temperature, wind speed, and air humidity, thus improving climatic conditions (Hamada and Ohta 2010; Baumgardner et al. 2012) and affecting lichen composition and diversity. The important driver of lower lichen diversity is higher anthropogenic disturbances in residential areas. Human activities clearly have large impacts on vegetation condition in the Rawa Danau area as demonstrated by increased burning, development of food crops agriculture, deforested areas replaced with grasses, sedges and ferns, and presence of weeds (van der Kaars et al. 2001). Extensive disturbances degrade the microhabitat quality, resulting in lower species diversity and abundance. Similar to the result of this study, low diversity of lichens in city areas of Muzaffarabad may be caused by human activities (Firdous et al. 2017). In urban areas, air pollution mainly by $\mathrm{SO}_{2}$ is a factor that reduces the abundance and distribution of lichen (Sett and Kundu 2016).

To conclude, this study has provided baseline data on lichen diversity as a bio-monitoring indicator for ecosystem health in Rawa Danau Nature Reserve. The lichen diversity and distribution is strongly influenced by environmental conditions. The results of this study are expected to be the basis for future research for monitoring changes in Rawa Danau Nature Reserve by focusing on lichen diversity and abundance. Periodical field works in the study area are therefore required for such kind of research.

\section{ACKNOWLEDGEMENTS}

The study was conducted with financial support from the Nagao Natural Research Foundation (NEF 2018). The authors would like to express their gratitude to the local community in Desa Cikedung, Serang, Banten for participating in the study and their hospitality. The authors would also like to acknowledge all of the students of Biology Education Department of Sultan Ageng Tirtayasa University who contributed to the study in various ways.

\section{REFERENCES}

Amman K, Herzig R, Liebendorfer L, Urech M. 1987. Multivariate correlation of deposition data of 8 different air pollutants to lichen data in a small town in Switzerland. Adv Aerobiol 51: 401-406.

Aptroot A, Sipman, H. 1993. Musaespora, a genus of pyrenocarpous lichens with campylidia, and other additions to the foliicolous lichen flora of New Guinea. Lichenologist 25 (2): 121-135.

Arup U, Søchting U, FrödénP. 2013. A new taxonomy of the family Teloschistaceae. Nordic J Bot 31: 16-83.

Asta J, Erhardt W, Ferretti M, Fornasier F, Kirschbaum U, Nimis PL, Purvis OW, Pirintsos S, Scheidegger C, van Haluwyn C, Wirth V. 2002. Mapping lichen diversity as an indicator of environmental quality. In: Nimis PL, Scheidegger C, Wolseley PA (eds), Monitoring with lichens Monitoring lichens, vol. 7 (4). NATO Science Series, Kluwer, Dordrecht, The Netherlands. 
Attanayaka ANPM, SC Wijeyaratne. 2013. Corticolous lichen diversity, a potential indicator for monitoring air pollution in tropics. J Nat Sci Found Sri Lanka 41 (2): 131-140.

Awang MB. 1995. Effects of air pollution on tropical plants, Proceedings of the International Seminar on the Simple Measuring and Evaluation Method on Air Pollution, Japan Society of Air Pollution (JSAP) and Environmental Research and Training Center (ERTC), Pathumthani, Thailand.

Batten L. 1976. Bird communities of some Killarney woodlands. Proc Royal Irish Acad 76B: 258-301.

Baumgardner D, Varela S, Escobedo FJ, Chacalo A. Ochoa C. 2012. The role of a peri-urban forest on air quality improvement in the Mexico City megalopolis. Environ Pollut 163: 174-183.

Blanco O, Crespol A, Divakar PK, Elix JA, Lumbsch HT. 2005. Molecular phylogeny of parmotremoid lichens (Ascomycota, Parmeliaceae). Mycologia 97 (1): 150-9.

BBKSDA. 2016.Informasi Kawasan Konservasi lingkup BBKSDA Jabar. http://bbksdajabar.ksdae.menlhk.go.id/wpcontent/uploads/2017/08/Profil-Bidwil-1-Fix_skw_1_rawa-danau.pdf [Indonesia]

Brako L. 1991. Phyllopsora (Bacidiaceae). Flora Neotropica Monographs 55: 1-66.

Brunialti G, Giordani P. 2003. Variability of lichen diversity in a climatically heterogeneous area (Liguria, NW, Italy). Lichenologist 35: 55-69.

Castello M, Skert N. 2005. Evaluation of lichen diversity as an indicator of environmental quality in the North Adriatic submediterranean region. Sci Total Environ 336: 201-214.

De Silva, C. M. S. M, S. P. Senanayake. 2015. Assessment of Epiphytic Lichen Diversity in Pine Plantations and Adjacent Secondary Forest in Peacock Hill, Pussellawa, Sri Lanka. Intl J Modern Bot 5 (2): 2937.

Dobson FS. 1992. Lichens An Illustrated Guide to The British and Irish Species. Stamford Press, Singapore.

Eldridge D, Skinner S, Entwisle TJ. 2003. NSW Biodiversity Report: Survey Guidelines for non-vascular plants. Botanic Gardens Trust, Sydney.

Elix JA. 2009. Physciaceae. Flora Aust. 57: 509-517.

Firdous, S.S, S. Khan, M. E, Ul Islam Dar, H, Shaheen, T. Habib, T. S Ullah. 2017. Diversity and Distribution of Lichens in Different Ecological Zones of Western Himalayas Pakistan. Bangladesh J Bot 46 (2): 805-811.

Gueidan, C, Savic, S, Thu S, H, Roux, C, Keller, C, Tibell, L, Prieto, M, Heiðmarsson, S, Breuss, O, Orange, A, et al. 2009. Generic classification of the Verrucariaceae (Ascomycota) based on molecular and morphological evidence: recent progress and remaining challenges. Taxon 58: 184-208.

Hamada S, Ohta T. 2010. Seasonal variations in the cooling effect of urban green areas on surrounding urban areas. Urban For Urban Green 9: 15-24.

Hilmo, O. Såstad, S. M. 2001. Colonization of old-forest lichens in a young and an old boreal Picea abies forest: an experimental approach. Biol Conserv 102: 251-259.

Liu D, Oh SO, Park JS, Hur JS. 2018. New Species and New Record of Genus Chrysothrix (Chrysotrichaceae, Arthoniales) from South Korea and Chile. Mycobiology 46 (3): 185-191. DOI: 10.1080/12298093.2018.1509511

Joshi Y, Upreti DK. 2007. Caloplaca awasthii, a New Lichen Species from India. Bot J Linn Soc 155 (1): 149-152,

Kantvilas G, Wdin M. 2015. Lichenicolous species of the Ascomycetes genus Arthonia Ach from Kangaroo Island. J Adelaide Bot Gard 29: $1-6$.

Knudsen K, Bungartz F. 2013. Chrysothrix galapagoana, a new species from the Galapagos Islands. Opuscula Philolichenum 12: 174-179.

Kuldeep S, Prodyut B. 2015. Lichen as a bio-indicator tool for assessment of climate and air pollution vulnerability: Review. Intl Res J Environ Sci 4 (12): 107-117.
Lücking R, Chaves JL, Sipman HJM, Umaña L, Aptroot A. 2008. A first assessment of the Ticolichen biodiversity inventory in Costa Rica: The genus Graphis, with notes on the genus Hemithecium (Ascomycota: Ostropales: Graphidaceae). Fieldiana (Botany) New Series 46: 1-131.

Lumbsch HT, Nash III TH. 2002. Pertusaria. In: Nash TH III, Ryan BD, Gries C, Bungartz F (eds.). Lichen Flora of the Great Sonora Desert, Vol. 1. Lichens Unlimited, Tempe.

Matusmoto M. Mizoguchi T. 1995. A simple and simultaneous measurement method of Sulphur dioxide in atmosphere using molecular diffusion sampler, International Seminar on the Simple Measuring and Evaluation Method on Air Pollution, Japan Society of Air Pollution (JSAP) and Environmental Research and Training Center (ERTC), Pathumthani, Thailand.

Mc Carthy PM. 2000. Key to The Saxicolous Taxa of Porina Lichenologist 32 (1): 1-13.

McMullin, RT, ID Thompson, Newmaster SG. 2013. Lichen conservation in heavily managed boreal forests. Conserv Biol 27 (5): 1020-1030.

Melisch R, Noor YR, Giesen W, Widjanarti H, Rudyanto, 1993. 1 appendices. An assessment of the importance of Rawa Danau for nature conservation and evaluation of resource use. Directorate General of Forest Protection and Nature Conservation and Asian Wetland Bureau-Indonesia, Bogor.

Nash TH, Ryan, BD, Gries, C, Bungartz, F, (eds.) 2004. Lichen Flora of the Greater Sonoran Desert Region. Vol 2.

Nimis PL, Scheidegger C, Wolseley PA. 2002. Monitoring with Lichens Monitoring Lichens (eds. PL Nimis, C Scheidegger, PA Wolseley), pp. 1 - 4. Kluwer Academic.

Paoli L, Loppi S. 2008. A biological method to monitor early effects of air pollution caused by the industrial exploitation of geothermal energy. Environ. Pollut 155: 383-388

Pitakpong A, Kraichak E, Papong KB, Muangsan N, Suwanwaree P, Lumbsch HT, Lucking R. 2015. New species and records of the lichen genus Graphis (Graphidaceae, Ascomycota) from Thailand. Lichenologist 47 (5): 335-342.

Puswald W, Kantvilas F, Mayrhofer H. Hafellia dissa and H. levieri. 1994. (lichenized, Ascomycetes, Physiaceae), two conticolous and lignocolous species in Tasmania. Muelleria 8 (2): 133-140.

Rout J, Pulakdas, Uperti DK. 2010. Epiphytic lichen diversity in a reserve forest in Southern Assam Northeast India. Trop Ecol 2: 281-288.

Schmidt FH, Ferguson JHA, 1951. Rainfall types based on wet and dry period ratios for Indonesia with western New Guinea. Jawatan Meteorologi dan Geofsika, Jakarta.

Sett R, Kundu M. 2016. Epiphytic Lichens: Their Usefulness as Bioindicators of Air Pollution. Danish J Res Environ Stud 3 (3): 17-24.

Sipman H. 2003. Provisional key for lichen genera and some species of Iran. http://www.bgbm.org/Sipman/keys/Irangenera.htm. First issue 17.9.2003.

Sipman HJM. 2009. Tropical urban lichens: observations from Singapore. Blumea 54: 297-299.

Stirton J. 1877. Description of recently discovered foreign lichens. Proc R Philos Soc Glasgow 10: 156-164.

Thor G. 1990. The lichen genus Chiodecton and five allied genera. Opera Botanica 103: 1-92.

Upreti DK, Divakar PK, Nayaka S. 2003. Notes on species of the lichen genus Phyllopsora in India. Bibliotheca Lichenologica 86: 185-191.

van der Kaars S, Penny D, Tibby J, Fluin J, Dam RAC, Suparan P. 2001. Late Quaternary palaeoecology, palynology and palaeolimnology of a tropical lowland swamp: Rawa Danau, West-Java, Indonesia. Palaeogeogr Palaeoclim Palaeoecol 171: 185-212.

van Dobben HF, ter Braak CJF. 1999. Ranking of epiphytic lichen sensitivity to air pollution using survey data: A comparison of indicator scales. Lichenologist 31 (1): 27-39.

Yulianto E, Tsuji H, Sukapti WS, Tanaka N. 2005. A holocene pollen and charcoal record from a tropical lowland swamp in Rawa Danau, West Java, Indonesia. Tropics 14 (2): 271-281. 